\title{
Management of Maize Stover with Underdoses Rates of Glyphosate Applications in No-Tillage ${ }^{1}$
}

\author{
Manejo da Palhada do Milho com Aplicações de Subdoses de Glyphosate em Plantio Direto
}

\author{
JASPER, S.P. ${ }^{2}$, PICOLI JR., G.J. ${ }^{3}$, VELINI, E.D. ${ }^{3}$, SOUSA, S.F.G. ${ }^{3}$, and CARBONARI, C.A. ${ }^{3}$
}

\begin{abstract}
Glyphosate has significant effects on the growth and development of plants when in underdoses. This work was developed to verify the effect of the application of glyphosate in underdoses in lignin synthesis and consequently decomposition of maize stover. Two experiments were conducted; the first one in a greenhouse for underdoses adjustments and the second one in the production area. The experimental design of the first trial was completely randomized with four replications. The treatments consisted in the application of the underdoses: $0,25,50$ and $100 \mathrm{~g} \mathrm{ha}^{-1}$ of glyphosate. In the production area, the experimental design was a randomized block with four replications, in underdoses: $0,12.5,25$ and $50 \mathrm{~g} \mathrm{ha}^{-1}$. The results were submitted to analysis of variance and regression. The underdoses of 25 g a.e. ha ${ }^{-1}$ in a greenhouse promoted $36 \%$ increase in productivity of stover, in addition to increasing the lignin content in $16 \%$, with no change in the unwanted growth of maize plants. In the production area, the concentration of $12.5 \mathrm{~g}$ a.e. ha $^{-1}$ of glyphosate reduced the lignin content and the other underdoses have not changed this feature in maize plants. None of the underdoses affected the height and biomass produced by the maize plants. The highest underdose tested promoted acceleration in the decomposition of maize stover.
\end{abstract}

Keywords: Zea mays, stover decomposition, lignification, growth stimulus.

RESUMO - O glyphosate apresenta importantes efeitos sobre o crescimento e desenvolvimento das plantas quando aplicado em subdoses. Assim, este trabalho foi desenvolvido com o objetivo de verificar o efeito da aplicação de subdoses do glyphosate na sintese de lignina e, consequentemente, na decomposição da palhada de milho. Foram realizados dois experimentos, sendo o primeiro em casa de vegetação e o segundo em área de produção. O delineamento experimental para o primeiro experimento foi o inteiramente casualizado com quatro repetições. Os tratamentos constituiram-se da aplicação das subdoses: 0, 25, 50 e $100 \mathrm{~g}$ e.. . ha $a^{1}$ de glyphosate. Na área de produção, o delineamento experimental adotado foi de blocos ao acaso com quatro repetições, e as subdoses utilizadas foram: $0,12,5,25$ e $50 \mathrm{~g}$ e.a. $\mathrm{ha}^{-1}$. Os resultados foram submetidos a análise de variância e ajuste de regressão. A subdose de $25 \mathrm{~g}$ e. $a$. ha $\mathrm{a}^{-1}$ em casa de vegetação promoveu aumento de $36 \%$ na biomassa das plantas, além de elevar o teor da lignina em 16\%, sem alteração na altura das plantas de milho. Na área de produção, a concentração de $12,5 \mathrm{~g}$ e.a. ha $\mathrm{a}^{-1}$ de glyphosate reduziu o teor de lignina, e as demais subdoses não alteraram essa característica nas plantas de milho. Nenhuma das subdoses afetou a altura e biomassa produzida pelas plantas de milho. A maior subdose testada promoveu aceleração na decomposição da palhada de milho.

Palavras-chave: Zea mays, decomposição de palhada, lignificação, estímulo de crescimento.

Recebido para publicação em 4.6.2015 e aprovado em 30.6.2015.

2 Universidade Federal do Paraná, Curitiba, PR, Brasil, <samir@ufpr.br>; ${ }^{3}$ Universidade Estadual Paulista Botucatu, SP, Brasil. 


\section{INTRODUCTION}

The no-tillage system is an effective strategy for improving agriculture sustainability, helping to minimize soil and nutrients losses by erosion (Caires et al., 2006). This management system has shown rapid growth in cultivated areas in Brazil, currently occupying some 31 million hectares (Febrapdp, 2013).

In the no-tillage system, there are factors, particularly with respect to the large amount of stover generated from second-crop maize, hampering the next crops sowing, such as soybeans (Almeida et al., 2008). To solve this problem, farmers handle the stover with clearing saws and chippers, or closed harrowing, fragmenting the stover in very tiny pieces, but this promotes increased traffic in farming and hence the risk of compaction, besides increasing the operating costs (Aratani et al., 2006).

On the other hand, in warmer regions, such as the Brazilian cerrado, the rapid decomposition of the stover is a problem for the no-tillage system consolidation, the deployment of crops that produce high amounts of stover being extremely important (Andreotti et al., 2008).

This stover decomposition rate determines its residence time on the soil surface. The faster its decomposition, the greater the release rate of nutrients, reducing, however, the soil protection. On the other hand, the higher the lignin content and the $\mathrm{C} / \mathrm{N}$ ratio present in the stover, the slower its decomposition (Floss, 2000).

Lignin is a highly complex phenolic molecule; these structures formed by the polymerization of paracoumaryl alcohol, coniferyl alcohol and sinapyl alcohol are associated to cellulose in the cell wall and have functions such as providing stiffness, impermeability and resistance to various types of biotic and abiotic stress (Eckardt, 2002; Raes et al., 2003; Cabané et al., 2004).

Glyphosate herbicide has, as a site of action, the enzyme EPSPs. When it acts, it blocks the shikimic acid pathway, thus impairing the production of complex phenolic compounds such as lignin (Galli \& Montezuma 2005; Franz et al., 1997; Weaver \& Hermmann, 1997).

Currently, glyphosate is the active ingredient that is most used in weed control and desiccation of cover crops for implementing non-tillage. However, there are other important effects of this herbicide on development and growth of plants which have been studied. Some studies have shown that the application of underdoses of glyphosate acts as a growth promoter in crops (Velini et al., 2008; Cedergreen et al., 2009; Dalley \& Richard Jr., 2010; E1-Shahawy \& Sharara, 2011 a,b; Silva et al., 2012), promotes the reduction of the rice plant lodging (Gitti et al., 2011), increases the extracted sugar content in sugarcane, while reducing the lignin content in this crop (Meschede et al., 2012). These effects are known as "hormesis", a term introduced by Ehrlich in 1943 to describe the phenomenon in which substances which are toxic in high doses are beneficial in underdoses (Calabrese, 2005).

Therefore, this work was developed with the objective of verifying the underdoses application effect of glyphosate in lignin synthesis in maize plants and correlate it to the interference of this phenolic complex in the decomposition of the residual stover.

\section{MATERIALS AND METHODS}

Maize seeds (Zea mays Hybrid 2B587Hx Herculex $^{\circledR}$ ) and herbicide Roundup Original ${ }^{\circledR}$ (480 g kg-1 a.e. of glyphosate) were used. The first experiment (2011) was conducted in a greenhouse, in order to select the herbicide underdoses for the field experiment. The experiment in production area was conducted in $2011 / 2012$.

\section{Experiment in a greenhouse}

The experiment in a greenhouse was conducted in a completely randomized design with four replications. Each experimental unit consisted of a plastic pot with a volumetric capacity of five liters, filled with Plant Max $^{\circledR}$ substrate, for maize seeding with a density equivalent to 70,000 seeds per hectare (two seeds per pot). The treatments consisted of 
application of the glyphosate herbicide in underdoses: 0, 25, 50 and $100 \mathrm{~g}$ a.e. ha ${ }^{-1}$. In all treatments with herbicide application, 0.5\% (v:v) of adjuvant Aterbane ${ }^{\circledR}$ was added. The treatments application was done at 28 days after sowing (DAS) in the maize plants in vegetative stage V4 (four fully unfolded leaves), with a laboratory-installed stationary spray and equipped with four nozzles of the DG series 11002 , spaced $0.50 \mathrm{~m}$, with pressure of $200 \mathrm{kPa}$ and a spray volume of $200 \mathrm{~L} \mathrm{ha}^{-1}$. The temperature at the time of application was $22{ }^{\circ} \mathrm{C}$, with relative humidity of $65 \%$.

\section{Experiment in a production area}

The area used in this experiment has been managed in the no-tillage system for 11 years, with rotation of soybeans and maize in summer and fallow in winter (spontaneous vegetation), and has clayey soil containing 165,385 and $450 \mathrm{~g} \mathrm{~kg}^{-1}$ of sand, silt and clay, respectively.

The experiment was conducted in a randomized block design with four replications. Each experimental unit had dimensions of ten meters long and four meters in width, consisting of four sowing rows spaced 0.85 meters, with a density of 70,000 seeds per hectare. At the maize sowing, fertilization with $300 \mathrm{~kg} \mathrm{ha}^{-1}$ of formulated fertilizer 08-28$16\left(\mathrm{~N}, \mathrm{P}_{2} \mathrm{O}_{5}, \mathrm{~K}_{2} \mathrm{O}\right)$ was performed and a coverage fertilization was done with $300 \mathrm{~kg} \mathrm{ha}^{-1}$ of urea, divided into two applications of $150 \mathrm{~kg} \mathrm{ha}^{-1}$ each, according to Raij et al. (1997).

In the experimental area, the end lines were considered as borders to avoid contamination among the experimental units at the time of treatment application. The treatments consisted of the application of the glyphosate herbicide in underdoses: 0, 12.5, 25 and 50 g a.e. ha ${ }^{-1}$. In all treatments with herbicide application, $0.5 \%(\mathrm{v}: \mathrm{v})$ of adjuvant Aterbane ${ }^{\circledR}$ was added. The treatments application was done at 28 days after sowing (DAS), with the maize plants in vegetative stage V4 (four fully unfolded leaves), with pressurized backpack sprayer at $\mathrm{CO}_{2}$, with constant pressure of $200 \mathrm{kPa}$, equipped with an application bar of two meters and with four spray nozzles Teejet XR 11002 VS, spaced 0.5 meters and set to apply a spray volume of
$200 \mathrm{~L} \mathrm{ha}^{-1}$. The air temperature at application was $28{ }^{\circ} \mathrm{C}$, with relative humidity of $90 \%$ and air velocity of $10 \mathrm{~km} \mathrm{~h}^{-1}$.

\section{Parameters evaluated}

The maize plants height was measured with a self-retracting tape measure from the ground to the insertion of the last fully expanded leaf. This measurement was performed in two plants per pot at 21 days after application (DAA) for the experiment in a greenhouse, and in ten plants at 150 DAA in the production area.

To determine the accumulation of biomass per pot, the plants were cut with scissors, weighed and packed in paper bags for drying in a forced circulation oven at $60^{\circ} \mathrm{C}$ for seven days. The procedure was repeated in the production area, but a linear meter of maize plants was cut, without the ear; later, the results were converted to biomass per hectare.

After weighing, the plants were ground in a circular rotor mill with knives (Marconi MA340) for determination of lignin content, quantifying cell walls free of proteins from the dry matter, according to Morrison's methodology (1977). About $100 \mathrm{mg}$ of sample were placed in $6 \mathrm{~mL}$ polypropylene cartridges (Applied) for solid-phase extraction (SPE), and sequentially subjected to washings with the following solutions: water at $100{ }^{\circ} \mathrm{C} ; 3 \%$ aqueous solution of sodium dodecyl sulfate (SDS) at $122{ }^{\circ} \mathrm{C} ; 85 \%$ aqueous solution of ethanol at $75{ }^{\circ} \mathrm{C}$; and acetone at $56^{\circ} \mathrm{C}$. A portion of $20 \mathrm{mg}$ of the washed material was packed in a centrifuge tube, and $500 \mu \mathrm{L}$ of acetyl bromide at $25 \%$ were added. The samples were heated at $70{ }^{\circ} \mathrm{C}$ for $30 \mathrm{~min}$, transferred to an ice bath and then neutralized by adding $0.9 \mathrm{~mL}$ of $\mathrm{NaOH} 2 \mathrm{M}$. Subsequently, $0.1 \mathrm{~mL}$ of hydroxylamine, and $2 \mathrm{~mL}$ of glacial acetic acid were added. The samples were centrifuged at $1,000 \mathrm{xg}$ for 5 minutes and the supernatant was submitted to spectrophotometric reading (UV/VIS GBC, model Cintra 40) at $280 \mathrm{~nm}$. The lignin concentration was obtained based on the lignin standard curve (Sigma), under the same conditions of the sample, and expressed in $\mathrm{mg}$ of lignin per gram of tissue. 
The residual stover mass was monitored in all plots to determine the stover decomposition rate during four months, and four replications randomly per plot were collected at $0,30,60$, 90 and 120 days after harvest, with the aid of a frame with an area of one square meter (Penati et al., 2005).

The results were submitted to analysis of variance; being significant, they were submitted to linear regression adjustment (Araldi et al., 2011) or quadratic (Toebe et al., 2012), with the aid of software SigmaPlot (Systat Software, 2006). Confidence interval for each means was also determined by the equation: $\mathrm{IC}=(\mathrm{t} \times \mathrm{stdev}) /$ root $\mathrm{nr}$, where $\mathrm{CI}=$ confidence interval; $\mathrm{t}=$ tabulated $\mathrm{t}$ value, at $10 \%$ probability; stdev $=$ standard deviation; and root $\mathrm{nr}=$ square root of the number of repetitions.

\section{RESULTS AND DISCUSSION}

The average plant height and ear insertion are important morphological parameters to assess maize crops due to the direct correlation with lodging and loss of grains at harvest (Li et al., 2007). The plants that were sown in the greenhouse and subjected to the application of underdoses of $0,25,50$ and $100 \mathrm{~g}$ a.e. ha ${ }^{-1}$ of glyphosate reached an average height of 89,97, 98 and $81 \mathrm{~cm}$, respectively (Figure 1). Plants subjected to an underdose of $100 \mathrm{~g}$ a.e. ha ${ }^{-1}$ had height reduced compared to the other treatments. The derivative equal to zero of the adjusted quadratic model demonstrates that the underdose to maximize the maize plants height is $42 \mathrm{~g}$ a.e. ha- $\mathrm{a}^{-1}$, resulting in a height of $98 \mathrm{~cm}$. For the adjusted model, the underdoses above $83 \mathrm{~g}$ a.e. ha ${ }^{-1}$ promoted reduction of plant height.

These data were important for the selection of underdoses of glyphosate used in the experiment in the production area. Plant height is an important variable to be observed when evaluating application tests of herbicide underdoses (Silva et al., 2012), especially with respect to the plants profile when subjected to the glyphosate molecule application (Godoy 2007; Velini et al., 2008).

When compared to other studies, the maize growth in this experiment under the no-tillage system (production area) was normal and plants lodging was not seen, which shows that their average height was within the normal range (Gomes et al., 2010). The glyphosate underdoses application did not affect plant height in the field (Figure 1).

The quadratic polynomial model adjusted to analyze the accumulation of maize biomass in a greenhouse and due to the glyphosate underdoses, was significant at $5.00 \%$. In the derivative equal to zero (Skoog et al., 2014), the model demonstrates that the crop biomass is maximized with the underdose of 38 g a.e. ha ${ }^{-1}$ (Figure 2).

There was a $26 \%$ increase in maize biomass in a greenhouse with the application of $25 \mathrm{~g}$ a.e. ha ${ }^{-1}$ of glyphosate, compared to the control. The other two underdoses (50 and 100 g a.e. ha ${ }^{-1}$ ) decreased 8 and 27\%,
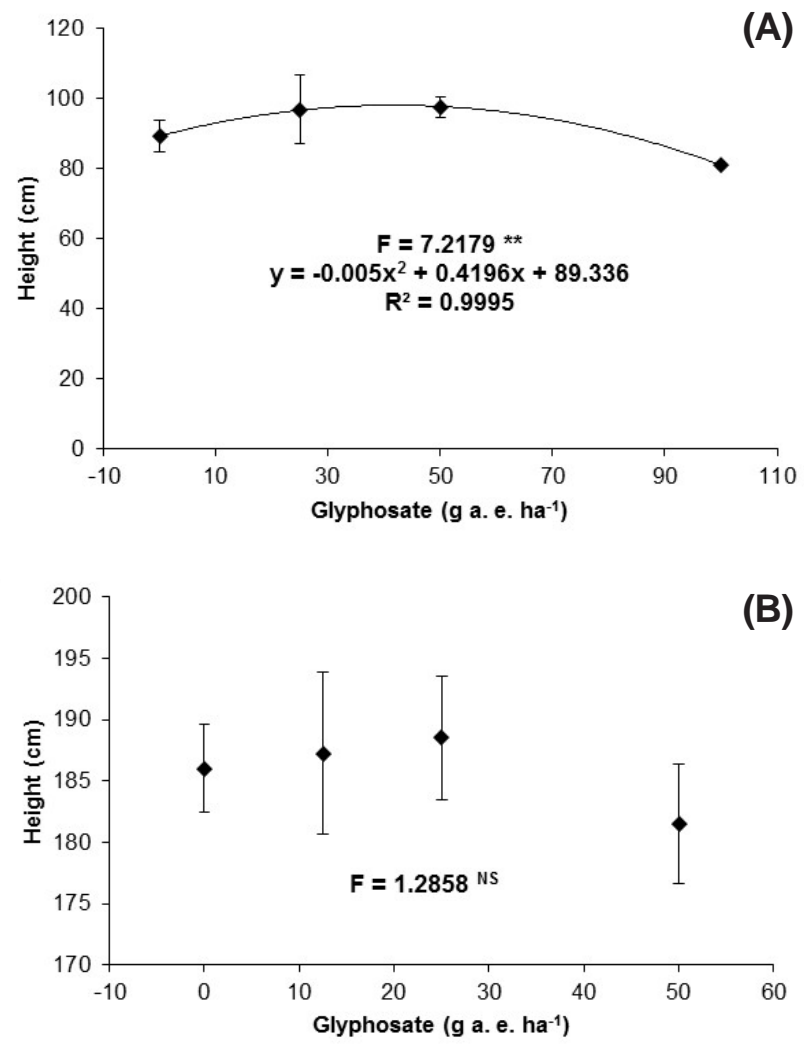

NS - non-significant $(\mathrm{p}>0.05), *$ significant $(\mathrm{p}<0.05)$ and ** significant $(\mathrm{p}<0.01)$.

Figure 1 - Height of maize plants. (A) Experiment in a greenhouse - evaluation at 21 DAA. (B) Experiment in the production area - evaluation after 150 DAA of the glyphosate. 
respectively, compared to the control. Therefore, the concentration of $100 \mathrm{~g}$ a.e. ha ${ }^{-1}$ was not used in the experiment in the production area. The maize biomass accumulation in a production area based on dry matter, was 7.20; $6.93 ; 7.31$; and $7.71 \mathrm{~kg} \mathrm{ha}^{-1}$, respectively, for the underdoses of $0,12.5,25$ and $50 \mathrm{~g} \mathrm{ha}^{-1}$. This hybrid biomass accumulation was lower when compared to the experiment conducted by Chioderoli et al. (2010), who have found an average yield of $9,652 \mathrm{~kg} \mathrm{ha}^{-1}$ employing irrigation. Higher accumulation of biomass is favorable in soil management conservation systems (Teixeira et al., 2010).

Glyphosate has as mechanism of action the inhibition of 5-enolpyruvylshikimate-3phosphate synthase (EPSPS), with consequent interruption of the shikimic acid pathway (Franz et al., 1997), which reduces the
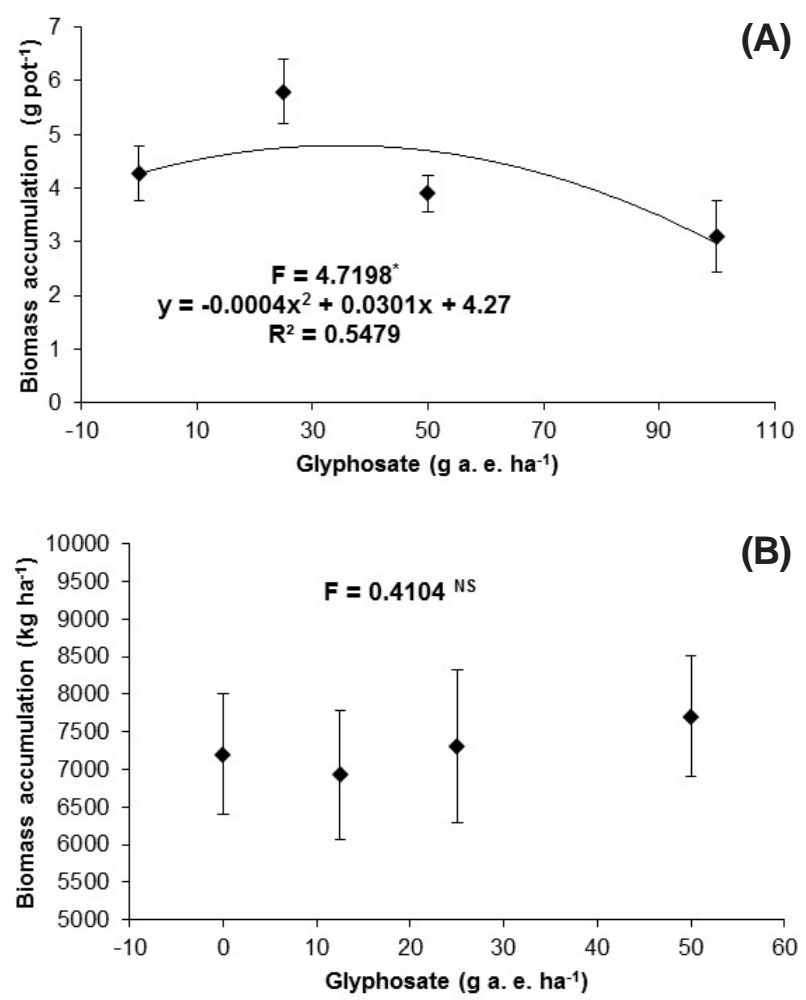

NS - non-significant $(\mathrm{p}>0.05)$, * significant $(\mathrm{p}<0.05)$ and $* *$ significant $(\mathrm{p}<0.01)$.

Figure 2 - Accumulation of biomass of maize plants. (A) Experiment in a greenhouse - evaluation at 21 DAA. (B) Experiment in the production area - evaluation after 150 DAA of the glyphosate. availability of the three aromatic amino acids: phenylalanine, tyrosine and tryptophan (Devine et al., 1993); therefore, it causes the formation of cinnamic acid and its derivatives, thereby inhibiting the production of more complex phenolic compounds such as lignin (Weaver \& Herrmann, 1997). Conflicting results were observed for the lignin content in maize for experiments in the greenhouse and in the production area. In the experiment conducted in a greenhouse, the plants showed an increase in lignin content in underdoses of 25 and $50 \mathrm{~g}$ a.e. ha ${ }^{-1}$, which promoted, respectively, levels of $10.2 \%$ and $10.3 \%$ of lignin, compared to $8.8 \%$ present in the control without herbicide application (Figure 3). For the underdose of 100 g a.e. ha-1 of glyphosate, the lignin content has not changed, being $8.6 \%$, which is very similar to the content found in the control.
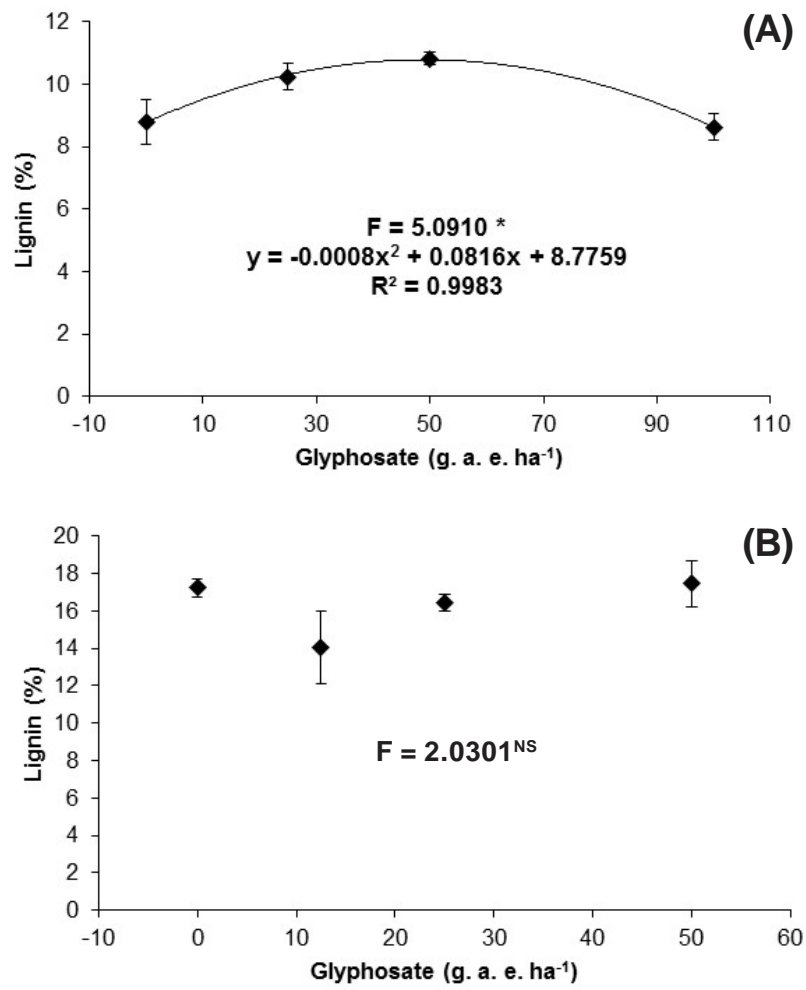

NS - non-significant $(\mathrm{p}>0.05),{ }^{*}$ significant $(\mathrm{p}<0.05)$ and $* *$ significant $(\mathrm{p}<0.01)$.

Figure 3 - Lignin content of the maize plants. (A) Experiment in a greenhouse - evaluation at 21 DAA. (B) Experiment in the production area - evaluation after 150 DAA of the glyphosate.

Planta Daninha, Viçosa-MG, v. 33, n. 3, p. 543-550, 2015 
The observed lignin increase can be interesting in some cases, as many authors have found that vegetable waste with higher lignin contents is more slowly decomposed, compared to plants of lower levels (Floss, 2000; Sainju et al., 2007; Oliveira et al., 2009; Teixeira et al., 2010).

For the lignin content found in the experiment carried out in the production area, it was not possible to adjust a significant quadratic polynomial model; however, it was observed by the confidence interval that only the underdose of $12.5 \mathrm{~g}$ a.e. $\mathrm{ha}^{-1}$ of the herbicide interfered in reducing the lignification rate of maize plants. The lignin contents observed in this experiment were $17.2 \%, 14.1 \%, 16.4 \%$ and $17.5 \%$ for the underdoses of $0,12.5,25$ and 50 g a.e. ha- ${ }^{-1}$, respectively (Figure 3 ).

These values were higher than those analyzed in the greenhouse. One hypothesis to explain these different results may be in the different plants stages at the time of collection of plant material for the analyses, a fact also confirmed by Fukushima et al. (2000). This demonstrates that apparently a temporary effect on the change of plant lignin contents occurs, but these changes do not persist until the final stages of the cycle, which does not contribute to significant changes in the composition of maize stover.

Carvalho et al. (2013) have reported that lignin synthesis can be inhibited with underdoses of glyphosate. A similar profile was observed for sugarcane with the application of underdoses of this same product in the production area (Meschede et al., 2012). Lignification, although a particular genetic trait for each of the plants, has a metabolic regulation which allows it to be manipulated by both extrinsic factors as by the regulation of genes that are interconnected to the biochemical pathways for synthesis and/or degradation of such polymer complex (Shi et al., 2012).

To evaluate the decomposition of maize stover, linear regression models were adjusted for each of the applied glyphosate underdoses (Figure 4). According to the linear regression intersection coefficient, the initial amount of the maize crop stover was: $7,314.4 ; 6,916.7$;
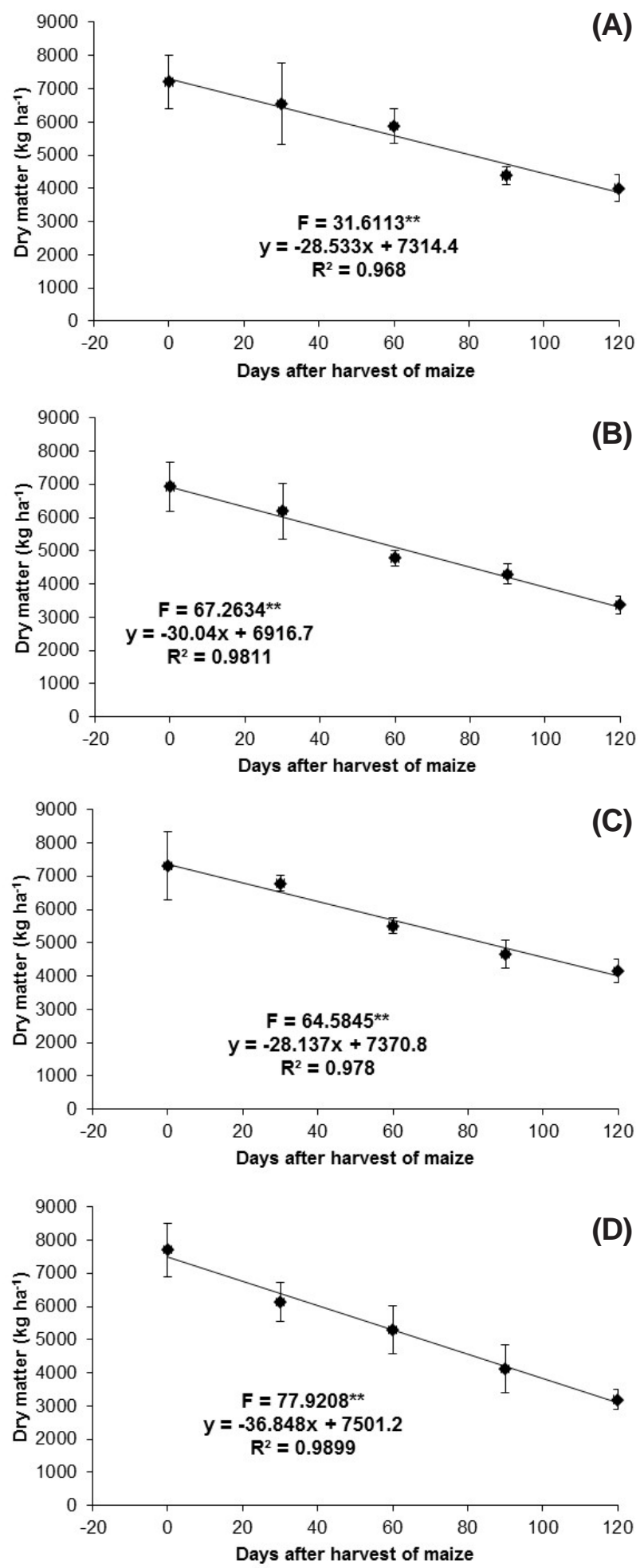

NS - non-significant $(\mathrm{p}>0.05), *$ significant $(\mathrm{p}<0.05)$ and ** significant $(\mathrm{p}<0.01)$.

Figure 4 - Decomposition of dry matter of maize plants in the production area due to time: (A) 0.0 ; (B) 12.5 ; (C) 25.0; (D) $50.0 \mathrm{~g}$ a.e. ha-1 glyphos. 
$7,370.8$; and $7,501.2 \mathrm{~kg} \mathrm{ha}^{-1}$, respectively, for the underdoses of $0,12,5,25$ and $50 \mathrm{~g}$ a.e. ha ${ }^{1}$ of glyphosate.

The line slope coefficient shows a daily maize stover decomposition of 29, 30, 28 and $37 \mathrm{~kg} \mathrm{ha}^{-1}$ for the underdoses of 0, 12.5, 25 and $50 \mathrm{~g}$ a.e. ha $\mathrm{h}^{-1}$ of glyphosate, respectively. After a period of 120 days, for the underdoses of $0,12.5,25$ and $50 \mathrm{~g}$ a.e. ha- ${ }^{-1}$ of glyphosate, decomposition was $44 \%, 51 \%, 43 \%$ and $59 \%$, respectively (Figure 4 ). There was acceleration in the stover decomposition concomitant to the higher underdose studied. Casa et al. (2003), when assessing the stover decomposition of that same crop in the Brazilian city of Passo Fundo, in Rio Grande do Sul, have reported decomposition of only $10 \%$ in the same period of 120 days. According to Alexander (1961), the observed differences can easily be explained by climatic changes during the period of testing, and especially with regard to low temperatures that directly interfere in microbial activity in the soil, which are responsible for the decomposition of organic matter.

In the experiment under controlled conditions, the underdoses of 25 and 50 g a.e. ha ${ }^{-1}$ caused an increase in plant biomass and lignin content, without significantly altering the development of maize plants. In the experiment in the production area, the concentration of $12.5 \mathrm{~g}$ a.e. $\mathrm{ha}^{-1}$ of glyphosate reduced the lignin content, and the other underdoses did not affect this trait in maize plants. None of the underdoses affected the height and biomass produced by maize plants in the field, and the greater underdose tested promoted acceleration in the maize stover decomposition.

\section{ACKNOWLEDGMENT}

To Coordenação de Aperfeiçoamento de Pessoal de Nivel Superior (CAPES; Coordination of Improvement of Higher Education Personnel).

\section{LITERATURE CITED}

ALEXANDER, M. Organic matter decomposition. In: ALEXANDER, M. (Ed.). Introduction to soil microbiology. New York: John Wiley, 1961. p. 139-162.
ALMEIDA, V. P. Rotação de culturas e propriedades físicas e químicas em latossolo vermelho de cerrado sob preparo convencional e semeadura direta em adoção. R. Bras. Ci. Solo, v. 32, n. 3, p. 1227-1237, 2008.

ARALDI, R. et al. Análises de fluorescência e consumo de água em Brachiaria decumbens após aplicação de herbicidas em pós-emergência. Planta Daninha, v. 29, p. 1053-1060, 2011. (Número Especial)

ARATANI, R. G. et al. Desempenho de semeadorasadubadoras de soja em Latossolo Vermelho muito argiloso com palha intacta de milho. R. Bras. Eng. Agríc. Amb., v. 10, n. 2, p. 517-522, 2006.

ANDREOTTI, M. et al. Produtividade do milho safrinha e modificações químicas de um latossolo em sistema plantio direto em função de espécies de cobertura após calagem superficial. Acta Sci. Agron., v. 30, n. 1, p. 109-115, 2008.

CABANÉ, M. et al. Condensed lignins are synthesized in poplar leaves exposed to ozone. Plant Physiol., v. 134, n. 2, p. 586-594, 2004.

CAIRES, E. F. et al. Calagem superficial e cobertura de aveia preta antecedendo os cultivos de milho e soja em sistema plantio direto. R. Bras. Ci. Solo, v. 30, n. 1, p. 87-98, 2006.

CALABRESE, E. J. Historical blunders: how toxicology got the dose-response relationship half right. Cellular Molec. Biol., v. 51, n. 7, p. 643-654, 2005.

CARVALHO, L. B. et al. Hormesis with glyphosate depends on coffee growth stage. An. Acad. Bras. Cienc., v. 85, n. 2, p. 813-821, 2013.

CASA, R. T. et al. Decomposição dos restos culturais do milho e sobrevivência saprofítica de Stenocarpella macrospora e Stenocarpella maydis. Fitopatol. Bras., v. 28, n. 4, p. 355-361, 2003.

CEDERGREEN, N. et al. Chemical stress can increase crop yield. Field Crops Res., v. 114, n. 1, p. 54-57, 2009.

CHIODEROLI, C. A. et al. Consorciação de braquiárias com milho outonal em plantio direto sob pivô central. Eng. Agríc., v. 30, n. 6, p. 1101-1109, 2010.

DALLEY, C. D., RICHARD JR, E. P. Herbicides as ripeners for sugarcane. Weed Sci., v. 58, n. 3, p. 329-333, 2010.

DEVINE, M.; DUKE, S. O.; FEDTKE, C. Oxygen toxicity and herbicidal action; Secondary physiological effects of herbicides. In: DEVINE, M.; DUKE, S. O.; FEDTKE, C. Physiology of herbicide action. New Jersey: Prentice-Hall, 1993. p. $177-188$.

EL-SHAHAWY, T. A.; SHARARA, F. A. A. Hormetic effect of glyphosate on wheat and associated weeds. Inter. J. Acad. Res., v. 3, n. 3, p. 520-523, 2011a.

Planta Daninha, Viçosa-MG, v. 33, n. 3, p. 543-550, 2015 
EL-SHAHAWY, T. A.; SHARARA, F. A. A. Hormesis influence of glyphosate in between increasing growth, yield and controlling weeds in faba bean. J. Am. Sci., v. 7, n. 2, p. 139-144, 2011b.

ECKARDT, N. A. Probing the mysteries of lignin biosynthesis: the crystal structure of caffeic acid/5hydroxyferulic acid 3/5-O methyltransferase provides new insights. Plant Cell, v. 14, n. 6, p. 1185-1189, 2002.

\section{FEDERAÇÃO BRASILEIRA DE PLANTIO DIRETO NA} PALHA - FEBRAPDP. Evolução da área de plantio direto no Brasil. Ponta Grossa: 2013. Disponível em: <http:// www.febrapdp.org.br/download/PD_Brasil_2013.I.pdf >. Acesso em: 11 maio, 2015.

FLOSS, E. Benefícios da biomassa de aveia ao sistema de semeadura direta. R. Plantio Direto, v. 57, n. 1, p. 25-29, 2000.

FRANZ, J. E.; MAO, M. K.; SIKORSKI, J. A. Glyphosate: a unique global herbicide. Washington, DC: American Chemical Society, 1997.

FUKUSHIMA, R. S. et al. Extração da lignina e emprego da mesma em curvas de calibração para a mensuração da lignina em produtos vegetais. R. Bras. Zootec., v. 29, n. 5, p. 1302-1311, 2000 .

GALLI, A. J. B.; MONTEZUMA, M. C. Glifosato: alguns aspectos da utilização do herbicida glifosato na agricultura. São Paulo: ACADCOM, 2005. 66 p.

GITTI, D. C. et al. Glyphosate como regulador de crescimento em arroz de terras altas. Pesq. Agropec. Trop., v. 41, n. 4, p. 500-507, 2011.

GODOY, M. C. Efeitos do glyphosate sobre o crescimento e absorção de fósforo pela soja. 2007. 53 f. Dissertação (Mestrado em Agronomia) - Faculdade de Ciências Agrárias, Universidade Estadual Paulista, Botucatu, 2007.

GOMES, L. S. et al. Resistência ao acamamento de plantas e ao quebramento do colmo em milho tropical. Pesq. agropec. bras., v. 45, n. 2, p. 140-145, 2010.

LI, Y. et al. The genetic relationship among plant-height traits found using multiple-trait QTL mapping of a dent corn and popcorn cross. Genome, v. 50, n. 4, p. 357-364, 2007.

MORRISON, I. M. A semi-micro method for the determination of lignin and its use in predicting the digestibility of forage crops. J. Sci. Food Agric., v. 23, n. 4, p. 455-463, 1977.

MESCHEDE, D. K. et al. Teores de lignina e celulose em plantas de cana-de-açúcar em função da aplicação de maturadores. Planta Daninha, v. 30, n. 1, p. 121-127, 2012.
OLIVEIRA, M. B. et al. Teor de lignina em plantas de Eucalyptus urophylla S. T. Blake tratadas com fitorreguladores. Silva Lusitana, v. 17, n. 1, p. 51-57, 2009.

PENATI, M. A. et al. Número de Amostras e Relação Dimensão: Formato da Moldura de Amostragem para Determinação da Massa de Forragem de Gramíneas Cespitosas. R. Bras. Zootec., v. 34, n. 1, p. 36-43, 2005.

RAES, J. et al. Genome-wide characterization of the lignifications toolbox in Arabidopsis. Plant Physiol., v. 133, n. 3, p. 1051-1071, 2003.

RAIJ, B. van.; CANTARELLA, H.; QUAGGIO, J. A.; FURLANI, A. M. C. (Ed.). Recomendações de adubação e calagem para o Estado de São Paulo. 2. ed. Campinas: Instituto Agronômico/Fundação IAC, 1997. 285 p. (Boletim Técnico, 100).

SAINJU, U. M. et al. Cover crop effect on soil carbon fractions under conservation tillage cotton. Soil Till. Res., v. 96, n. 1-2, p. 205-218, 2007.

SHI, H. et al. Overexpression of cotton (Gossypium hirsutum) dirigent 1 gene enhances lignifications that blocks the spread of Verticillium dahlia. Acta Biochim. Biophys. Sinica, v. 44, n. 7, p. 555-564, 2012.

SILVA, J. C. et al. Efeito hormese de glyphosate em feijoeiro. Pesq. Agropec. Trop., v. 42, n. 3, p. 295-302, 2012.

SKOOG, D. A.; WEST, D. M.; HOLLER, F. J. Fundamentals of Analytical Chemistry. 9.ed. Fort Worth: Saunders College, 2014. 1072 p.

SYSTAT SOFTWARE Inc - SSI. Sigmaplot for Windows, version 10, 2006. Disponível em: <http:// www.systat.com.products/sigmaplot>. Acesso em: 17 ago. 2013.

TEIXEIRA, C. M. et al. Liberação de macronutrientes das palhadas de milheto solteiro e consorciado com feijão-deporco sob cultivo de feijão. R. Bras. Ci. Solo, v. 34, n. 2, 497-505, 2010.

TOEBE, M. et al. Modelos para a estimação da área foliar de feijão de porco por dimensões foliares. Bragantia, v. 71, n. 1, p. 77-41, 2012.

VELINI, E. D. et al. Glyphosate applied at low doses can stimulate plant growth. Pest Manage. Sci., v. 64, n. 4, p. 489-496, 2008.

WEAVER, L. M.; HERRMANN, K. M. Dynamics of the shikimate pathway in plants. Trends Plant Sci., v. 2, n. 9, p. 346-351, 1997. 